УДК 634.0.114

doi: $10.31251 /$ pos.v1i3.40

Check for updates

\title{
ОЦЕНКА ЗАПАСОВ ФИТОМАССЫ И ПЛОДОРОДИЯ СЕРЫХ ПОЧВ ЗАЛЕЖЕЙ
}

\author{
(C) 2018 O.А. Сорокина
}

Адрес: ФГБОУ ВО «Красноярский государственный аграрный университет», ул.Мира, 90, г. Красноярск, 660049, Россия.Email: geos0412@mail.ru

Цель исследования. Выявить специифику формирования запасов и структуры фитомассы, а также трансформации плодородия серых почв залежей при различном их использовании в лесостепной зоне. Место и время проведения. Исследования проводились на трех объектах (чистая залежь, залежь, используемая под сенокос и залежь, повторно вовлеченная в пашню) в Красноярской и АчинскоБоготольской лесостепи Красноярского края с 2011 по 2016 г2.

Методология. На всех объектах проводили сопряженный учет запасов и общей структурь надземной травянистой фитомассы и показателей плодородия серых почв. Рассчитали статистические параметры достоверности различий и корреляционной взаимосвязи продуктивности растений с показателями эффективного и потенциального плодородия постагрогенных серых почв залежей.

Основные результаты. Восстановительные сукиессии надземной травянистой растительности залежей лесостепной зонь Красноярского края свидетельствуют о переходной от корневищной к дерновинной стадии. Растительность залежи Красноярской лесостепи представлена пырейноразнотравным фитоценозом с долей рудеральных видов около 30 \%. Флора залежей АчинскоБоготольской лесостепи отличается более богатым видовым составом с увеличением доли бобовых видов, при этом сорный компонент в травостое залежей занимает примерно $30 \%$ Богатство видового состава трав на залежах в обоих районах исследования зависит от условий увлажнения; показано, что запасы продуктивной влаги в почвах Ачинско-Боготольской лесостепи существенно выле, чем в Красноярской лесостепи. Использование залежи под сенокос ускоряет наступление дерновинной стадии сукцессии и приводит к вытеснению разнотравья злаковым компонентом за счет уплотнения почвы при сенокошении. В условиях пашни в составе надземной растительности преобладает доля злаков за счет выращиваемых полевых культур, таких как овес и пшеница, в то же время резко возрастает доля разнотравья за счет сорного компонента.

Общие запасы надземной травянистой фитомассы максимальные на чистых залежах в обоих районах исследования, что подтверждается статистически. Исключением является распаханная залежь с посевом овса, биомасса которого резко нарастала от летнего к осеннему сроку учета. Более продуктивными являются залежи Ачинско-Боготольской лесостепи за счет оптимальной влажности почв в течение всей вегетации. Залежи, используемые под сенокосы, не отличаются высокой продуктивностью, запасы травянистой фитомассы на них практически одинаковые в обоих районах исследования.

Установлено, что вовлечение залежей в пашню существенно ухудшает показатели потенщиального плодородия почв. Динамика показателей эффективного почвенного плодородия (нитратный $u$ аммонийный азот) зависят от характера использования участка; при распашке залежи усиливается минерализация органического вещества, увеличивается содержание нитратного и аммонийного азота. Выявлено статистически достоверное изменение комплекса почвенно-агрохимических свойств чистых залежей в сторону улучшения. Между запасами фитомассы и показателями потенциального и эффективного плодородия почв в Ачинско-Боготольской лесостепи установлена более тесная корреляионная зависимость, по сравнению с Красноярской лесостепью, за счет оптимального режима увлажнения.

Заключение. Установлены максимальные запасы надземной фитомассы на чистых залежах в переходной от корневищной $\kappa$ дерновинной стадии сукцессии, что приводит к повышению плодородия постагрогенных серых почв. В структуре фитомассы залежей преобладает разнотравный компонент. Использование залежей под сенокосы снижает продуктивность растений, увеличивает в травостое долю злакового компонента, ускоряет наступление дерновинной стадии сукиессии и ухудшает показатели почвенного плодородия. При введении залежи в пашню зафиксирована минимальная продуктивность фитомассы и снижение биогенной аккумулячии.

Ключевые слова: лесостепь; залежь; сенокос; пашня; влажность; запасы фитомассы; варьирование; серые почвы; плодородие; биогенные показатели; корреляционная зависимость

Цитирование: Сорокина О.А. Оиенка запасов фитомассы и плодородия серых почв залежей // Почвы и окружающая среда. 2018. № 1(3). С.170-179. 


\section{ВВЕДЕНИЕ}

Наиболее отчетливо последствия агрогенного изменения экосистем проявляются в смене продуктивности и видового состава фитоценозов. Сельскохозяйственная деятельность, как правило, приводит к изменению растительности: обеднению генетических ресурсов, стиранию региональных черт флоры, уменьшению богатства и экологического разнообразия. Изучение продуктивности залежей в ходе сукцессий растительного сообщества является важным аспектом (Анциферова, 2005; Люри, 2008). Запасы и структура фитомассы при восстановлении и дальнейшем использовании залежей являются определяющим фактором, влияющим на почвообразование и плодородие почв. Они дают представление о скорости биологического круговорота, раскрывают пути приспособления различных экосистем к меняющимся экологическим факторам воздействия (Титлянова, 2000; Кудеяров, 2006; Ковалева, 2005). Современная информация по количественной оценке продуктивности фитомассы залежей и сопряженной динамике плодородия почв в Средней Сибири весьма ограничена.

Цель исследований: оценить запасы и общую структуру надземной фитомассы залежей Ачинско-Боготольской и Красноярской лесостепи при различном направлении их использования, а также дать оценку корреляционной зависимости между запасами фитомассы и показателями плодородия постагрогенных серых почв.

\section{МАТЕРИАЛЫ И МЕТОДЫ ИССЛЕДОВАНИЙ}

По агроклиматическому районированию территория Красноярской лесостепи относится к холодно-умеренному подпоясу умеренного пояса, к области нормального увлажнения с ГТК=1. Среднегодовая температура воздуха отрицательная $\left(-1,8^{\circ} \mathrm{C}\right)$. Климат Ачинско-Боготольской лесостепи резко континентальный, достаточно увлажненный $(\Gamma T К=1,4)$. Средняя многолетняя температура воздуха колеблется от $0^{\circ}$ до $+1^{\circ} \mathrm{C}$. На рисунке 1 представлено географическое положение районов исследования.

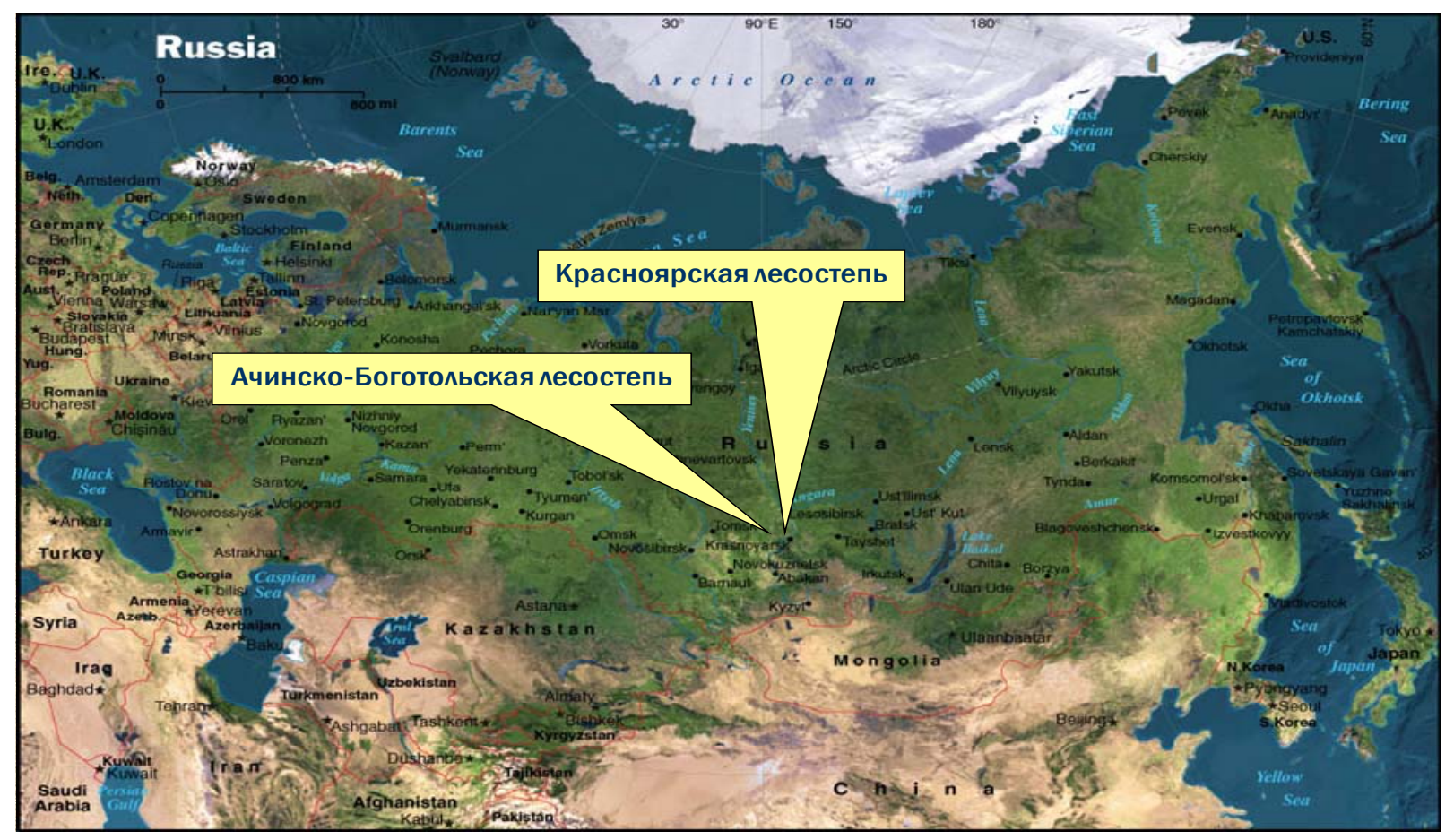

Рисунок 1. Районы исследования в лесостепной зоне Красноярского края

Исследования проводили в 2011-2016 гг. на пробных площадях чистых, то есть не зарастающих лесом залежей, а также залежей, повторно вовлеченных в пашню и используемых под сенокосы. На чистой залежи Ачинско-Боготольской лесостепи установлена переходная стадия сукцессии (от корневищной к дерновинной). Растительность залежи под сенокосом представлена, преимущественно, луговым фитоценозом, характерным для лесостепной зоны. В Красноярской 
лесостепи чистая разнотравно-злаковая залежь также представляет переходную стадию сукцессии от корневищной к дерновинной. Залежь под сенокосом характеризуется разнотравно-пырейным фитоценозом. Распаханные залежи использовались под посевы зерновых культур в течение трех лет без применения удобрений (1 год-пшеница, 2 год - овес, 3 год - пар).

Серые постагрогенные почвы в Красноярской и Ачинско-Боготольской лесостепей развиты на коричнево-бурых глинах. Они имеют полно развитый профиль со следующим общим строением: О (13 см) - AYра (15-21 см) -AEL (12-18см) - BEL (15-31см) - BT (14-23см) - BC (20-23см) - C.

Запасы фитомассы (т/га) на всех объектах учитывали посредством укосов по рамке 0,5 х 0,5 м в пятикратной повторности. Количественная оценка запасов воздушно-сухой фитомассы проводилась в два срока: в период максимального развития вегетативной массы (1 укос в конце июня) и при окончании вегетации (2 укос в конце августа). Образцы почвы отбирали из слоев 0-10 и 10-20 см в десятикратной повторности. Общепринятыми методами определили содержание гумуса, общего азота (Nобщ), элементов минерального питания: аммонийного азота (N-NH4), нитратного азота (N-NO3), подвижного фосфора (P2O5) и обменного калия (К2О). Рассчитали коэффициенты пространственного варьирования $(\mathrm{Cv}, \%)$ всех показателей, достоверность различий (tфакт по критерию Стьюдента) запасов фитомассы (Mcp), а также коэффициенты парной корреляции (r) между запасами фитомассы и почвенно-агрохимическими свойствами (Мср).

\section{РЕЗУЛЬТАТЫ ИССЛЕДОВАНИЯ И ИХ ОБСУЖДЕНИЕ}

В проведенных исследованиях установлено, что на разновозрастных залежах Красноярского и Ачинско-Боготольского лесостепных природных округов встречается более 16 видов травянистых растений, среди них имеются как естественные для природных условий виды растений, так и рудеральные виды. В экологическом отношении растительность залежей представлена видами, характерными для лугово-степных фитоценозов. Травостой залежей обоих районов исследования характеризуется преобладанием разнотравья и злаковых, а доля бобовых видов незначительна.

Залежь в Красноярской лесостепи представлена пырейно-разнотравным фитоценозом. Общее проективное покрытие составляет $80 \%$. Большинство видов трав относится к луговым (около $40 \%$ ). Однако в травостое принимают участие и степные виды (около 20\%), что характерно для открытых массивов южной части Красноярской лесостепи. Доминирующие позиции в фитоценозах залежей занимают крупно-травные растения. В экологическом отношении растительность таких залежей Красноярской лесостепи представлена, в основном, мезоксерофитами, которые характерны для лугово-степных фитоценозов.

Залежь в Ачинско-Боготольской лесостепи представляет собой переходную от корневищной к дерновинной стадию залежной сукцессии. Встречается более 20 видов растений, треть из которых сорные. Наиболее существенную роль в проективном покрытии (70-80\%) занимают мезофиты, характерные для луговых ценозов.

Продуктивность надземной травянистой биомассы в постагрогенных ландшафтах лесостепной зоны Красноярского края напрямую зависит от условий увлажнения. Запасы продуктивной влаги в почвах залежей всех объектов Ачинско-Боготольской лесостепи характеризуются как хорошие в слое 0-20 см (табл.1), что связано с лучшими условиями увлажнения. Задернованная поверхность снижает испарение влаги из почвы, улучшает развитие травостоя на залежи, что оказывает влияние на показатели эффективного плодородия почвы и создание оптимальных условий для развития растений.

Объекты исследования в Красноярской лесостепи характеризуются удовлетворительными запасами продуктивной влаги. В этом районе максимальные запасы влаги зафиксированы на чистой залежи. Они составляют 28,4 мм в слое 0-20 см, что также приводит здесь к формированию более высокой продуктивности. На распаханной залежи и сенокосе обоих зон исследования запасы продуктивной влаги характеризуются как удовлетворительные.

Получены низкие коэффициенты пространственного варьирования запасов продуктивной влаги, особенно в постагрогенных серых почвах Ачинско-Боготольской лесостепи. Неравномерность уплотнения почв при работе сеноуборочной техники на сенокосах по сравнению с распаханными массивами несколько повышает пространственную неоднородность запасов продуктивной влаги. Формирующийся здесь микрорельеф с западинами и небольшими повышениями способствует увеличению пространственной пестроты. 
Таблица 1

Запасы продуктивной влаги (Мср, мм) в слое 0-20 см в постагрогенных серых почвах залежей и их пространственное варьирование $(\mathrm{Cv}, \%)$

\begin{tabular}{|l|c|c|c|c|c|c|}
\hline \multirow{2}{*}{ Зона } & \multicolumn{7}{|c|}{ Объекты } \\
\cline { 2 - 7 } & \multicolumn{2}{|c|}{ чистая залежь } & \multicolumn{2}{c|}{ сенокос на залежи } & \multicolumn{2}{c|}{ распаханная залежь } \\
\cline { 2 - 7 } & Мср & Сv, \% & Mcp & Cv, \% & Мср & Cv, \% \\
\hline Красноярская лесостепь & 28,4 & 21,4 & 22,3 & 17,5 & 23,8 & 9,2 \\
\hline $\begin{array}{l}\text { Ачинско-Боготольская } \\
\text { лесостепь }\end{array}$ & 42,6 & 2,3 & 36,2 & 12,8 & 36,2 & 4,1 \\
\hline
\end{tabular}

В лесостепной зоне чередуются значительно отличающиеся по фитомассе две природные зоны - лес и степь (луга). Сравнивая продуктивность залежей, объектов наших исследований с продуктивностью лугово-степной зоны по Н.И. Базилевич и Л.Е. Родину (1971), их можно охарактеризовать как луговые степи, запасы воздушно-сухой фитомассы которых составляют от 2,75 до 6,52 т/га (табл. 2). Исходя из данных А.Г. Воронова (1987), изученные нами залежи по продуктивности соответствуют естественным фитоценозам лесостепной зоны.

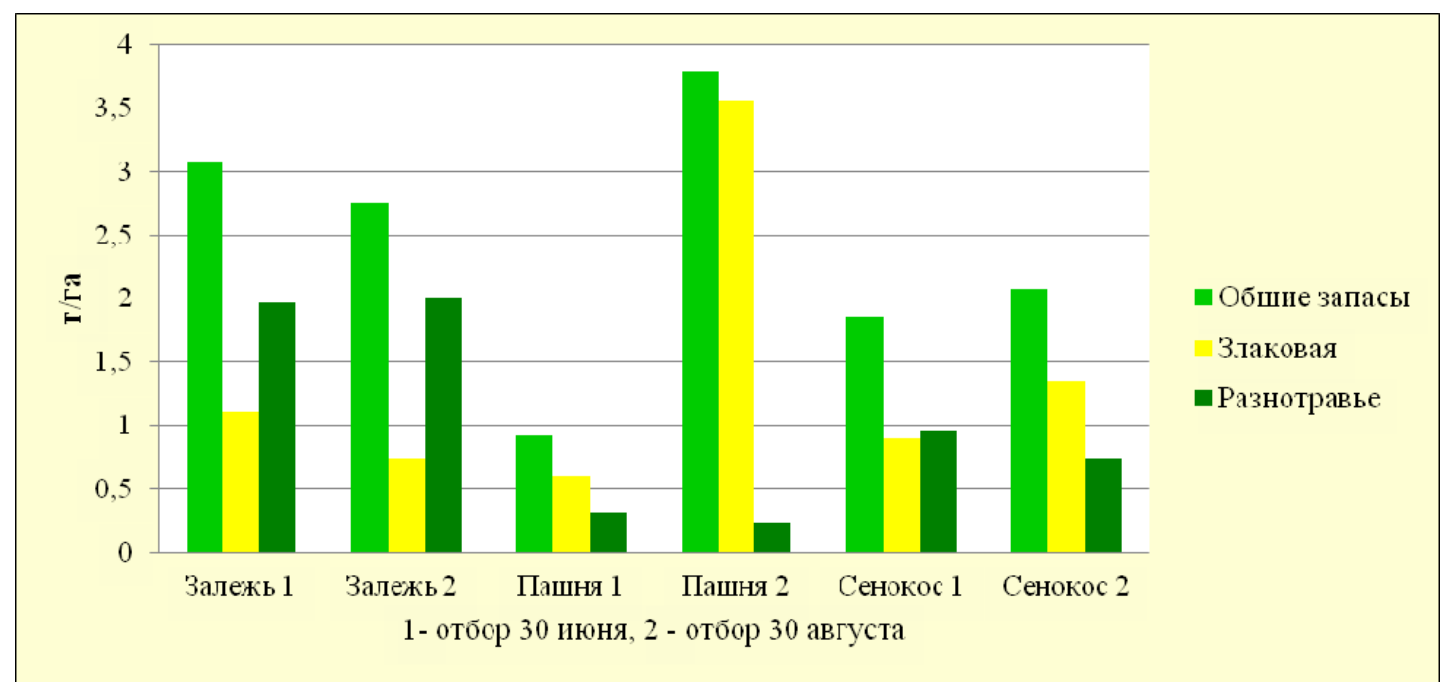

Рисунок 2. Общие запасы и структура фитомассы залежей (т/га) при различном использовании в Красноярской лесостепи

Биоценозы залежей Красноярской лесостепи характеризуются меньшей продуктивностью травянистой фитомассы по сравнению с Ачинско-Боготольской лесостепью. Это может быть связано с более выраженными засушливыми условиями Красноярской лесостепи в июне-июле 2012 года. На залежи продуктивность фитомассы более высокая, чем на сенокосе, что вполне закономерно. Если на чистой залежи Красноярской лесостепи в структуре фитомассы преобладало разнотравье, то в структуре биомассы сенокоса, особенно ко второму сроку укоса, доминировал злаковый компонент (рис.2). Максимальные запасы фитомассы на пашне в Красноярской лесостепи во второй срок определения объясняются интенсивным развитием овса во вторую половину вегетации, когда прошли обильные дожди, что привело к активному нарастанию надземной фитомассы, в структуре которой, закономерно, преобладал злаковый компонент.

В Ачинско-Боготольской лесостепи растительность чистой залежи также представляет собой переходную от дерновинной к корневищной стадии сукцессии. Как указывалось выше, распаханную залежь используют под посевы без внесения удобрений. Растительность залежи под сенокосом представлена, преимущественно, луговым фитоценозом, характерным для АчинскоБоготольской лесостепи. На залежи и сенокосе в Ачинско-Боготольской лесостепи наиболее существенную роль в проективном покрытии занимают мезофиты.

Максимальная продуктивность фитомассы укосов в Ачинско-Боготольской лесостепи отмечается на чистой залежи в оба срока. На других объектах отмечена невысокая продуктивность укосов, что объясняется сложными гидротермическими условиями. В июне-июле 2012 года на всей 
территории Красноярского края была засуха. Когда производились укосы в первом сроке, развитие травостоя было в два раза меньше нормы. Высокие значения фитомассы на чистой залежи АчинскоБоготольской лесостепи связаны с выраженным микрорельефом участка при выровненном мезорельефе, что очень характерно для данной зоны. Микрозападины и небольшие повышения способствовали большему задержанию влаги и, следовательно, увеличению развития травостоя.

Травянистая растительность залежей Ачинско-Боготольской лесостепи характеризуется обилием разнотравья и меньшей долей злаковых (рис. 3). Самое интенсивное нарастание вегетативной массы трав отмечается в почве пашни, освоенной из-под залежи в АчинскоБоготольской лесостепи, что связано с сильным развитием в паровом поле сорного компонента, в структуре которого преобладало разнотравье.

В структуре травостоя залежей несколько преобладает доля разнотравья, также присутствуют и злаковые виды. Участки сенокосов, прошедших стадию залежей, характеризуются невысоким уровнем продуктивности фитомассы и удовлетворительным ее отрастанием после сенокошения. Использование залежей под сенокосы, особенно к концу вегетации (2 срок укоса), приводит к вытеснению разнотравья и существенному увеличению злаков. Участки сенокосов можно отнести к разнотравно-злаковым. Это также свидетельствует о более интенсивном проявлении здесь дерновинной стадии сукцессии, усиливающейся при уплотнении почвы от работающей сеноуборочной техники.

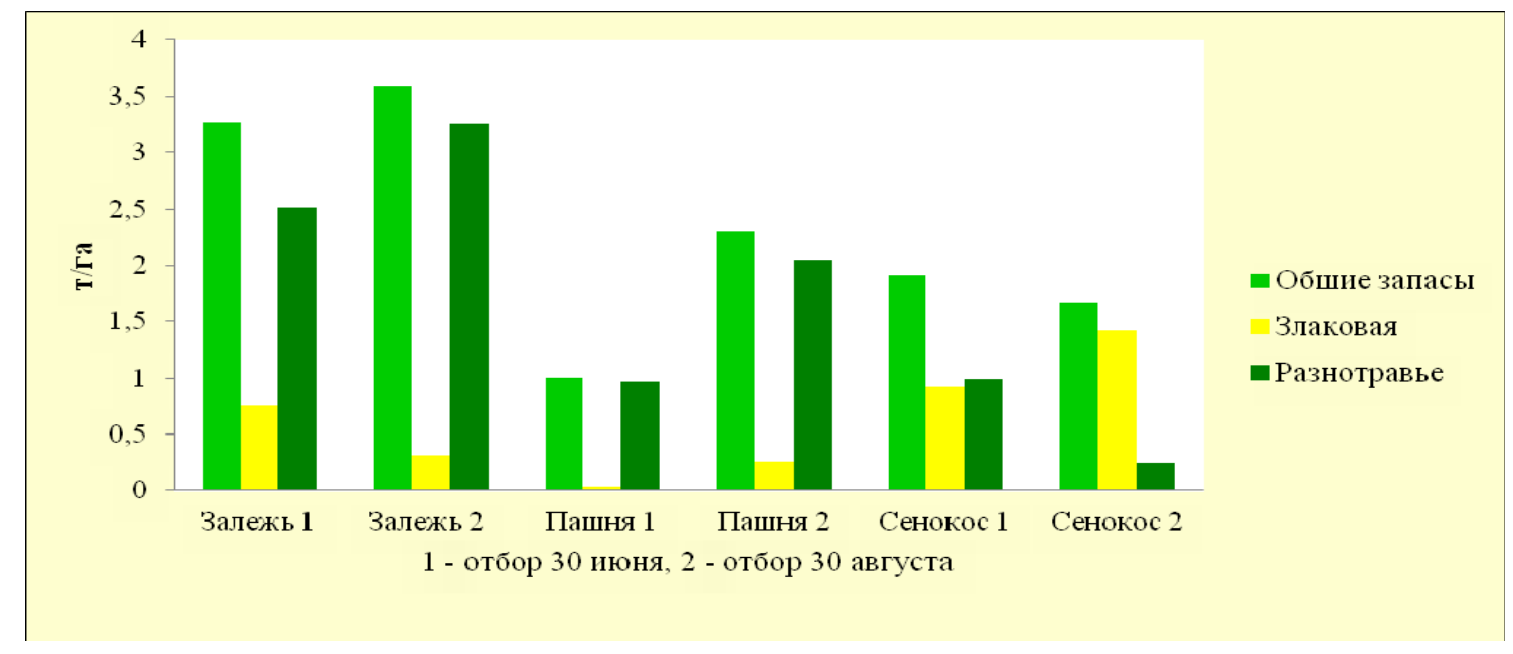

Рисунок 3. Общие запасы и структура фитомассы залежей (т/га) при различном использовании в Ачинско-Боготольской лесостепи

Разнотравье чистых и используемых под сенокосы залежей различается между собой по кормовому значению. Среди них есть как отлично и хорошо, так и удовлетворительно поедаемые растения. В разнотравье изученных залежей практически не встречаются вредные и ядовитые виды. Сено отличается высокой питательностью и энергетической ценностью. Увеличение доли злакового компонента в составе травостоя залежных сенокосов повышает количество сахаров и улучшает кормовую ценность биомассы трав (Косяненко, 2005). Низкая доля бобовых видов обедняет надземную травянистую фитомассу протеинами, что характерно для большинства кормовых угодий лесостепной зоны Красноярского края.

Таким образом, максимальные запасы надземной травянистой фитомассы в оба срока определения получены на залежи в Ачинско-Боготольской лесостепи. Это связано с более высокой влагообеспеченностью данной зоны и сильнее выраженным микрорельефом почвы.

Различия по запасам фитомассы между объектами исследования статистически подтверждаются. Критерий достоверности Стьюдента ( $\mathrm{t}$ факт) в большинстве случаев превышает теоретическое значение ( $\mathrm{t}$ теор. $=2,1)$, что следует из таблицы 2. Самые высокие коэффициенты пространственного варьирования запасов фитомассы характерны для чистых залежей, где более выражена куртинистость напочвенного покрова. Незначительное варьирование надземной биомассы отмечено на пашне, освоенной из-под залежи. Максимальная продуктивность фитомассы и ее менее выраженное пространственное варьирование зафиксировано на чистых разнотравно-злаковых залежах Ачинско-Боготольской лесостепи (табл. 2). 
Статистические параметры запасов фитомассы залежей (т/га)

Таблица 2 при их различном использовании (ср. из 5 повт.)

\begin{tabular}{|c|c|c|c|c|c|c|c|}
\hline \multirow{4}{*}{ Объекты } & \multirow{4}{*}{$\begin{array}{c}\text { Статистические } \\
\text { параметры }\end{array}$} & \multicolumn{6}{|c|}{ Укосы по годам } \\
\hline & & \multicolumn{2}{|c|}{1} & \multicolumn{2}{|c|}{2} & \multicolumn{2}{|c|}{3} \\
\hline & & \multicolumn{6}{|c|}{ сроки укосов } \\
\hline & & 1 & 2 & 1 & 2 & 1 & 2 \\
\hline \multicolumn{8}{|c|}{ Красноярская лесостепь } \\
\hline $\begin{array}{l}\text { Чистая } \\
\text { залежь }\end{array}$ & $\begin{array}{l}\text { Mcp } \\
\text { Cv, \% } \\
t_{\text {факт }}\end{array}$ & $\begin{array}{l}3,14 \\
23,2 \\
t_{1}-t_{2} \quad 4,9\end{array}$ & $\begin{array}{l}6,18 \\
34,9 \\
t_{1}-t_{2} \quad \mathbf{4 , 8}\end{array}$ & $\begin{array}{ll}3,07 & \\
19,8 & \\
t_{1}-t_{2} & \mathbf{8 , 2}\end{array}$ & $\begin{array}{ll}2,75 & \\
16,7 & \\
t_{1}-t_{2} \quad \mathbf{2 , 5}\end{array}$ & $\begin{array}{l}3,14 \\
35,3 \\
t_{1}-t_{2} \quad 1,7\end{array}$ & $\begin{array}{l}4,62 \\
30,0 \\
-\end{array}$ \\
\hline $\begin{array}{l}\text { Сенокос на } \\
\text { залежи }\end{array}$ & $\begin{array}{l}\text { Mcp } \\
\text { Cv, \% } \\
t_{\text {факт }}\end{array}$ & $\begin{array}{l}3,02 \\
16,2 \\
t_{1}-t_{3} \quad 0,2\end{array}$ & $\begin{array}{l}4,42 \\
3,7 \\
t_{1}-t_{3} \quad \mathbf{2 , 5}\end{array}$ & $\begin{array}{l}1,86 \\
18,3 \\
t_{1}-t_{3} \quad \mathbf{2 , 2}\end{array}$ & $\begin{array}{ll}2,08 & \\
21,3 & \\
t_{1}-t_{3} \quad \mathbf{2 , 5}\end{array}$ & $\begin{array}{ll}2,48 & \\
22,8 & \\
t_{1}-t_{3} \quad 1,2\end{array}$ & $\begin{array}{l}2,54 \\
19,4 \\
t_{1}-t_{3} \mathbf{3 , 2}\end{array}$ \\
\hline $\begin{array}{l}\text { Распаханная } \\
\text { залежь }\end{array}$ & $\begin{array}{l}\text { Mcp } \\
\mathrm{Cv}, \% \\
\mathrm{t}_{\text {факт }}\end{array}$ & $\begin{array}{l}1,98 \\
7,9 \\
\mathrm{t}_{2}-\mathrm{t}_{3} \quad \mathbf{6 , 4}\end{array}$ & $\begin{array}{l}3,76 \\
2,8 \\
\mathrm{t}_{2}-\mathrm{t}_{3} \quad \mathbf{2 , 4}\end{array}$ & $\begin{array}{l}0,92 \\
20,4 \\
\mathrm{t}_{2}-\mathrm{t}_{3} \quad \mathbf{2 , 3}\end{array}$ & $\begin{array}{l}3,79 \\
20,3 \\
\mathrm{t}_{2}-\mathrm{t}_{3} \quad \mathbf{4 , 3}\end{array}$ & $\begin{array}{ll}2,18 & \\
25,0 & \\
\mathrm{t}_{2}-\mathrm{t}_{3} & 0,9\end{array}$ & $\begin{array}{l}- \\
- \\
-\end{array}$ \\
\hline \multicolumn{8}{|c|}{ Ачинско-Боготольская лесостепь } \\
\hline $\begin{array}{l}\text { Чистая } \\
\text { залежь }\end{array}$ & $\begin{array}{l}\text { Mcp } \\
\text { Cv, \% } \\
t_{\text {факт }}\end{array}$ & $\begin{array}{l}3,29 \\
20,1 \\
\mathrm{t}_{1}-\mathrm{t}_{2} \quad \mathbf{5 , 5}\end{array}$ & $\begin{array}{l}6,52 \\
4,4 \\
t_{1}-t_{2} \quad 7,8\end{array}$ & $\begin{array}{|ll|}3,27 & \\
38,7 & \\
t_{1}-t_{2} \quad \mathbf{3 , 6} \\
\end{array}$ & $\begin{array}{ll}3,58 & \\
17,1 \\
t_{1}-t_{2} \quad \mathbf{3 , 5}\end{array}$ & $\begin{array}{ll}4,24 & \\
20,4 & \\
t_{1}-t_{2} \quad 0,7\end{array}$ & $\begin{array}{l}7,16 \\
11,7 \\
- \\
\end{array}$ \\
\hline $\begin{array}{l}\text { Сенокос на } \\
\text { залежи }\end{array}$ & $\begin{array}{l}\text { Mcp } \\
\text { Cv, \% } \\
t_{\text {факт }}\end{array}$ & $\begin{array}{l}3,36 \\
8,6 \\
t_{1}-t_{3} \quad 0,3\end{array}$ & $\begin{array}{ll}3,99 & \\
3,4 & \\
t_{1}-t_{3} \quad \mathbf{8 , 0}\end{array}$ & $\begin{array}{|ll|}1,91 & \\
23,2 & \\
\mathrm{t}_{1}-\mathrm{t}_{3} & \mathbf{2 , 3} \\
\end{array}$ & $\begin{array}{ll}1,67 & \\
26,4 & \\
t_{1}-t_{3} \quad 5,6\end{array}$ & $\begin{array}{ll}2,86 & \\
38,2 & \\
t_{1}-t_{3} \quad 1,8\end{array}$ & $\begin{array}{l}4,18 \\
21,8 \\
t_{1}-t_{3} \quad \mathbf{5 , 5}\end{array}$ \\
\hline $\begin{array}{l}\text { Распаханная } \\
\text { залежь }\end{array}$ & $\begin{array}{l}\text { Mcp } \\
\text { Cv, \% } \\
t_{\text {факт }}\end{array}$ & $\begin{array}{l}2,11 \\
7,4 \\
\mathrm{t}_{2}-\mathrm{t}_{3} \quad \mathbf{5 , 7}\end{array}$ & $\begin{array}{ll}3,96 & \\
2,8 & \\
\mathrm{t}_{2}-\mathrm{t}_{3} \quad 0,5\end{array}$ & $\begin{array}{|ll|}1,0 & \\
28,6 & \\
\mathrm{t}_{2}-\mathrm{t}_{3} & \mathbf{2 , 7} 7 \\
\end{array}$ & $\begin{array}{ll}2,30 & \\
22,3 & \\
t_{2}-t_{3} & 2,0 \\
\end{array}$ & $\begin{array}{ll}3,8 & \\
24,6 & \\
\mathrm{t}_{2}-\mathrm{t}_{3} \quad 1,4 \\
\end{array}$ & $\begin{array}{l}- \\
- \\
-\end{array}$ \\
\hline
\end{tabular}

Условная оценка продуктивности пашни, введенной в оборот после залежного состояния, свидетельствует о колебаниях урожайности биомассы зерновых культур (пшеницы, овса) и об интенсивном развитии сорной растительности на паровых полях (3 год укоса), особенно при более высоких запасах влаги в Ачинско-Боготольской лесостепи. Участки пашни при паровании были плохо обработаны, не проводилась борьба с сорняками, о чем свидетельствует высокая доля сорного компонента в структуре фитомассы, особенно в конце вегетации.

Исследования показали, что самое высокое содержание гумуса, общего азота (табл. 3), обменных оснований, а также максимальная степень насыщенности основаниями характерна для почв чистой залежи, что подтверждается статистически. При введении залежи в пашню происходит достоверное снижение количества гумуса, общего азота, суммы обменных оснований и расширение отношения углерода к азоту. По показателям потенциального плодородия почвы сенокосов занимают промежуточное положение. Содержание нитратного и аммонийного азота в большей степени зависят от характера повторного использования залежи, а не от района исследований, что говорит о существенном влиянии резкой смены экологических условий при агрогенных воздействиях на основные показатели плодородия почв.

Установлены более тесные корреляционные зависимости запасов фитомассы чистых залежей с показателями потенциального и эффективного плодородия серых почв Ачинско-Боготольской лесостепи в условиях их лучшего увлажнения (табл. 3). Здесь отмечается сильная зависимость продуктивности фитомассы чистой залежи и сенокоса с содержанием в почве нитратной формы азота. Высокие величины коэффициентов корреляции получены между запасами фитомассы и основными показателями эффективного плодородия почв. Как следует из таблицы 3, эти коэффициенты составляют: 0,81 с нитратным азотом, 0,75 - с подвижным фосфором и 0,9 - с обменным калием. Следовательно, продуктивность чистой залежи и сенокоса определяется в большой степени этими агрохимическими показателями. Более благоприятные гидротермические условия, оптимальные водно-физические свойства (запасы почвенной влаги, плотность сложения, структурное состояние) усиливают тесноту связи продуктивности и свойств серых почв залежей Ачинско-Боготольской лесостепи. Здесь ярче выражена биогенная аккумуляции, интенсивнее протекает дерновый процесс с одновременным проявлением слабых элювиально-глеевых явлений. Зафиксировано большее число 
случаев тесной корреляционной зависимости запасов фитомассы с показателями плодородия почв в период максимального развития травостоя (1 укос).

Корреляционная зависимость (r) запасов надземной фитомассы и свойств (Mcp)

Таблица 3 серых почв залежей

\begin{tabular}{|c|c|c|c|c|c|c|c|c|c|c|c|c|}
\hline \multirow[t]{3}{*}{ Объекты } & \multirow{2}{*}{\multicolumn{2}{|c|}{ Гумус, \% }} & \multirow{2}{*}{\multicolumn{2}{|c|}{$\begin{array}{c}\text { Общий азот, } \\
\text { \% }\end{array}$}} & \multicolumn{8}{|c|}{ Элементы питания, мг/кг почвы } \\
\hline & & & & & \multicolumn{2}{|c|}{$\mathrm{N}-\mathrm{NO}_{3}$} & \multicolumn{2}{|c|}{$\mathrm{N}-\mathrm{NH}_{4}$} & \multicolumn{2}{|c|}{$\mathrm{P}_{2} \mathrm{O}_{5}$} & \multicolumn{2}{|c|}{$\mathrm{K}_{2} \mathrm{O}$} \\
\hline & Mcp & $\mathrm{r}$ & Mcp & $\mathrm{r}$ & Mcp & $\mathrm{r}$ & Mcp & $\mathrm{r}$ & Mcp & $\mathrm{r}$ & Mcp & $\mathrm{r}$ \\
\hline \multicolumn{13}{|c|}{ Красноярская лесостепь } \\
\hline $\begin{array}{l}\text { Чистая } \\
\text { залежь }\end{array}$ & 6,6 & $-0,67$ & 0,31 & $-0,8$ & 9,0 & $-0,22$ & 8,4 & $-0,69$ & 157 & 0,64 & 181 & $\mathbf{0 , 4 3}$ \\
\hline $\begin{array}{l}\text { Сенокос на } \\
\text { залежи }\end{array}$ & 5,3 & 0,67 & 0,24 & 0,63 & 1,9 & 0,09 & 6,1 & 0,13 & 148 & $\mathbf{0 , 7 8}$ & 171 & 0,77 \\
\hline $\begin{array}{l}\text { Распаханная } \\
\text { залежь }\end{array}$ & 4,3 & $-0,7$ & 0,19 & $-0,28$ & 12,0 & 0,62 & 11,4 & 0,16 & 308 & 0,06 & 197 & $-0,94$ \\
\hline \multicolumn{13}{|c|}{ Ачинско-Боготольской лесостепь } \\
\hline $\begin{array}{l}\text { Чистая } \\
\text { залежь }\end{array}$ & 8,1 & $\mathbf{0 , 8 9}$ & 0,45 & 0,85 & 4,1 & 0,94 & 6,2 & $\mathbf{0 , 3 4}$ & 107 & 0,42 & 168 & 0.48 \\
\hline $\begin{array}{l}\text { Сенокос на } \\
\text { залежи }\end{array}$ & 5,1 & $-0,36$ & 0,24 & $-0,41$ & 2,9 & $\mathbf{0 , 8 3}$ & 5,2 & 0.1 & 157 & $\mathbf{0 , 8 5}$ & 105 & $\mathbf{0 , 8 8}$ \\
\hline $\begin{array}{l}\text { Распаханная } \\
\text { залежь }\end{array}$ & 3,7 & 0,65 & 0.17 & 0,54 & 16,9 & 0,65 & 12,9 & $\mathbf{0 , 4 2}$ & 85 & $\mathbf{0 , 1 8}$ & 133 & $-0,06$ \\
\hline
\end{tabular}

На распаханной залежи при активизации процессов минерализации, особенно в первые годы освоения, в обоих районах исследования получена достаточно тесная корреляционная связь с содержанием в почве нитратного азота. Характерны более высокие коэффициенты парной корреляции между запасами фитомассы с содержанием гумуса и общего азота на сенокосе Красноярской лесостепи, что связано с более низкой обеспеченностью этой почвы нитратным азотом в условиях недостаточного увлажнения.

\section{ЗАКЛЮЧЕНИЕ}

Таким образом, по запасам надземной травянистой фитомассы максимальная продуктивность характерна для чистых залежей лесостепной зоны Красноярского края. В структуре их травостоя преобладает разнотравный компонент, по сравнению со злаковым, при очень малой доле бобовых и рудеральных видов. Максимальные запасы надземной травянистой фитомассы получены на залежи в Ачинско-Боготольской лесостепи, где отмечается более высокая влагообеспеченность зоны и сильнее выраженный микрорельеф почвы, способствующий большему накоплению влаги и увеличению развития травостоя.

На залежах, используемых под сенокосы, разнотравные виды вытесняются злаковыми, что свидетельствует о более сильном проявлении здесь дерновинной стадии сукцессии. Для распаханных залежей в условиях низкой культуры земледелия характерно снижение продуктивности, увеличение доли сорного компоненте и усиление корреляционной зависимости запасов фитомассы от содержания в почве нитратного азота. Наиболее тесные корреляционные зависимости между свойствами почв, а также между свойствами почв и запасами фитомассы проявляются на залежи Ачинско-Боготольской лесостепи, где сильнее выражены процессы биогенной аккумуляции и установлено наличие дернового процесса.

Теснота связи между продуктивностью залежей и свойствами серых почв выше в АчинскоБоготольской лесостепи, что определяется более высокими запасами продуктивной влаги. Введение залежи в пашню и использование под сенокос снижает тесноту корреляции надземной фитомассы с показателями потенциального плодородия и усиливает связь с эффективным плодородием. Наиболее ярко биогенная аккумуляция проявляется в обоих районах исследования на чистых залежах. По комплексной оценке плодородия почвы и продуктивности биоценозов оптимальными показателями характеризуются чистые залежи обоих районов исследования. В Ачинско-Боготольской лесостепи залежи характеризуются более высоким плодородием. 


\title{
ЛИТЕРАТУРА
}

1. Анииферова O.A. Динамика растительности и свойств почв на молодых залежах Тамбовской равнины и Замландского полуострова. Калининград, Изд-во КГТУ, 2005. 315 с.

2. Базилевич Н.И., Родин Л.Е. Продуктивность и круговорот элементов в естественных и культурных фитоценозах (по материалам СССР) // Биологическая продуктивность и круговорот химических элементов в растительных сообществах. Л.: Наука, 1971. С. 5-31.

3. Воронов А.Г. Биогеография с основами экологии. М.: Изд-во МГУ, 1987. 260 с.

4. Ковалева Ю.П. Структура и динамика запасов растительного вещества в залежных экосистемах степной зоны, находящихся на различных стадиях восстановления // Природная и антропогенная динамика наземных экосистем: Матер. Всерос. конф. (Иркутск,11-15 октября 2005 г). Иркутск: Изд-во Иркутского технического университета, 2005. С. 326-329.

5. Косяненко Л.П. Луговое кормопроизводство Сибири. Красноярск: Изд-во КрасГАУ, 2005.244 с.

6. Кудеяров В.Н. Роль почв в круговороте углерода // Почвоведение. 2005. №8. С. 915-923.

7. Люри Д.И., Горячкин С.В., Караваева Н.А., Нефедова Т.Г., Денисенко Е.А. Закономерности вывода из оборота сельскохозяйственных земель России и мире и процессы постагрогенного развития залежей // Агроэкологическое состояние и перспективы использования земель России, выбывших из активного сельскохозяйственного оборота. М., 2008. С. 45-71.

8. Титлянова A.A., Kocblx Н.П. Изменение растительного покрова и первичной продукции в Южной Сибири за последние 150 лет. // Проблемы региональной экологии: Матер. Второй Всерос. конф. (Томск, февраль 2000). Новосибирск, Изд-во СО РАН, 2000. С. 46-47.

Поступила в редакичию 02.11.2018

Принята 03.12.2018

Опубликована 05.12.2018

Сведения об авторе:

Сорокина Ольга Анатольевна - профессор, доктор биологических наук, кафедра почвоведения и агрохимии ФГБОУ ВО Красноярский ГАУ (Красноярск, Россия); geos0412@mail.ru

Автор прочитал и одобрил окончательный вариант рукописи

(с)) С Сатья доступна по лицензии Creative Commons Attribution 4.0 License

\section{ESTIMATION OF PHYTOMASS STOCK AND GRAY SOIL FERTILITY OF ABANDONED LAND}

\section{(C) 2018 O.A. Sorokina}

Address: Krasnoyarsk State Agrarian University, Mira str., 90, Krasnoyarsk city, 660049, Russia. Email: geos0412@mail.ru

\begin{abstract}
Aim of the study. To assess phytomass structure and production, as well as gray soil (Greyzemic Phaeozems (Aric) fertility of abandoned arable land under different land use in the forest-steppe.

Location and time of the study. The study was carried out at three sites: 1)abandoned arable land under natural revegetation, 2) abandoned arable land used for haymaking and 3) abandoned arable land once more ploughed for grain crops pproduction) in the Krasnoyarsk and Achinsk-Bogotol forest-steppe of the Krasnoyarsk Krai (Russia) from 2011 to 2016.
\end{abstract}

Methodology. In all key study sites the general structure of aboveground phytomass and fertility indicators of gray soils were determined. The data were analyzed statistically, and the differences and correlation coefficients were considered statistically significant at $P \leq 0.05$.

Main results. Revegetation succession of the abandoned arable land in the forest- steppe zone displayed transition from the rhizome to the bunch stage. The vegetation of the Krasnoyarsk forest-steppe abandoned site was represented by the phytocenosis of grasses and forbs with $30 \%$ of ruderal species. The flora of the Achinsk-Bogotol forest-steppe abandoned site had greater plant species richness with increased contribution of legumes and 30\% of ruderals. Plant species richness at both study sites depended on water regime. The productive soil water content at the the Achinsk-Bogotol site was significantly higher than at the Krasnoyarsk site. The use of abandoned land for haymaking was found to accelerate the bunch stage of vegetation succession, substituting herbs and grasses by grasses and forbs due to soil compaction because of 
haymaking. The above-ground phytomass of the abandoned, but once more used for grain crop production, being dominated by the respective crops (oats and wheat), had an increased contribution of herbs andgrasses due to ruderal species.

The total aboveground phytomass stocks were estimated to be maximal $(P \leq 0.05)$ at the abandoned sites under natural revegetation in both regions. The site cropped to oats was an exception, as oats increased its aboveground phytomass during the growing season, resulting in the drastic increase from the summer to the autumn sampling dates. Due to their optimal soil water regime, the abandoned sites in the Achinsk-Bogotol forest-steppe were more productive, while the sites under haymaking were less productive and practically similar in both regions.

Intensive biogenic accumulation was found to be characteristic for the abandoned arable lands. However, the renewed arable use was shown to decrease significantly soil potential fertility. The actual soil fertility, as judged by the nitrate and ammonium nitrogen content, was shown to depend on land use, as ploughing increases soil organic matter mineralization and hence soil nitrate and ammonium content. The closer positive correlation between the aboveground phytomass and soil actual and potential fertility indicators in the Achinsk-Bogotol forest-steppe was most likely resultant from the optimal soil water regime there.

Soil fertility of abandoned lands was shown to depend on their subsequent land use. Natural revegetation significantly improved soil agrochemical properties and biogenic indicators.

Conclusion. The maximal aboveground phytomass was found to develop under natural revegetation during transition from rhizome to bunch stage of vegetation succession, which leads to biogenic accumulation and hence increased soil fertility. Grasses and herbs dominate in the aboveground phytomass. Haymaking at the abandoned revegetating sites results in decreased phytomass production and increased contribution of grasses, which accelerates successional changes towards the bunch stage and decreases soil fertility. The renewed use of the abandoned land for grain crtop production decreases phytomass production and biogenic accumulation.

Keywords: abandoned land; forest-steppe; revegetation; haymaking; arable land; Greyzemic Phaeozems (Aric); soil moisture; aboveground phytomass; gray soils; soil fertility; biogenic indicators; correlation analysis

Citation: Sorokina O.A. Estimation of phytomass stock and gray soil fertility of abandoned land // The Journal of Soils and Environment. 2018. 1(3): 170 - 179. (in Russian with English abstract).

\section{REFERENCES}

1. Antsiferova O.A. Vegetation dynamics and soil properties at young abandoned lands of the Tambov Plain and Zamland Peninsula. Kaliningrad: KSTU Publishing House, 2005. 315 p. (in Russian)

2. Bazilevich N.I., Rodin L.E. Productivity and turnover of elements in natural and cultural phytocenoses (according to the USSR data). In book: Biological productivity and turnover of chemical elements in plant communities. Leningrad: Nauka Pbs., 1971, p. 5-31. (in Russian)

3. Voronov A.G. Biogeography with the basics of ecology. M: Moscow State University Pubs., 1987. 260 p. (in Russian)

4. Kovaleva $Y u$. $P$. The structure and dynamics of plant matter stocks in the abandoned ecosystems of the steppe zone at different stages of revegetation, In book: Natural and anthropogenic dynamics of terrestrial ecosystems: Proc.of the Russian. Conference (Irkutsk, October 11-15, 2005). Irkutsk: Publishing Irkutsk Technical University, 2005. p.326-329. (in Russian)

5. Kosyanenko L.P. Meadow forage production in Siberia. Krasnoyarsk: KrasGAU Pubs., 2005. 244 p. (in Russian)

6. Kudeyarov V.N. The role of soil in carbon cycle, Eurasian Soil Science, 2005, $N^{\circ} 8, p .808-815$.

7. Luri D.I., S.V. Goryachkin, N.A. Karavaeva, T.G. Nefedova, E.A. Denisenko. Patterns of land withdrawal from the of agricultural turnover in Russia and the world and the processes of postagrogenic development of abandoned land. In book: Agroecological status and prospects for the use of lands, withdrawn from active agricultural turnover in Russia. Moscow, 2008. p. 45-71. (in Russian)

8. Titlyanova A.A., Kosykh N.P. Changes in land cover and primary production in South Siberia over the past 150 years. In book: Problems of Regional Ecology: Proc.of the All-Russian Conference (Tomsk, 2000). Novosibirsk: SB RAS Pbs. 2000. P. 46-47. (in Russian) 


\section{About the author:}

Sorokina Olga A. - Professor, Doctor of Biol. Sci., Department of Soil Science and Agrochemistry of Krasnoyarsk State Agrarian University (Krasnoyarsk, Russia); geos0412@mail.ru

The author read and approved the final manuscript

(cc) Er The article are available under Creative Commons Attribution 4.0 License 